\title{
THE ADDIS COUNT IN THE PROGNOSIS OF ACUTE NEPHRITIS IN CHILDHOOD*
}

\author{
BY

\begin{abstract}
MARGARET D. GILES, M.D., D.C.H.
(From the Department of Medical Paediatrics, Glasgow University and the Royal Hospital for
\end{abstract} \\ Sick Children, Glasgow)
}

The problem of assessing the extent of the renal damage following an attack of acute haemorrhagic nephritis has been the subject of much investigation. Renal function tests of various kinds have been described and undoubtedly are helpful if taken in conjunction with the clinical picture and the progress of the individual case. The reports of the prognosis of these cases, however, are still conflicting and therefore unsatisfactory.

Many of the tests depend on the rate of excretion of a chemical constituent of the blood or urine, e.g., urea, creatinine, water, etc., and, ds might be expected, the results of various tests on the same patient are often remarkably uniform. Van Slyke's standard urea clearance test observes this principle and is deservedly popular, especially in adults where one can be reasonably certain of obtaining accurate samples of urine. In children, however, the collecting of specimens of urine is difficult, and it is probably true to say that the renal excretion tests in children are of less value than in adults.

In 1925, Addis introduced a method of assessing renal function by counting the cellular constituents of the urinary sediment. He evolved a standard technique and his results showed that he was able to detect abnormalities in renal function which were not apparent by the more usual excretion tests. In this way he was able to estimate the prognosis in cases of acute haemorrhagic nephritis (1931). The Addis count has also been found to be of value in assessing the renal damage in other diseases, e.g., erythema nodosum (Wallgren, 1939), rheumatic fever (Goldring and Wykroff, 1930; and Nathhorst, 1940), pneumonia (Goldring, 1931) and scarlet fever (Lyttle, 1933).

Addis (1925) standardized his technique as follows. Fluids were withheld during the afternoon and evening. At 8 p.m. urine was passed and discarded. Thereafter all urine passed until 8 a.m. was collected, that is, a twelve-hour specimen. The volume was measured. Ten $\mathrm{ml}$. of the urine were then taken

* This work was carried out during the tenure of a Muirhead Scholarship. and, after centrifuging, reduced to a known volume, usually about $1 \mathrm{ml}$. which contained all the cellular elements of the $10 \mathrm{ml}$. of urine. Using a haemocytometer, the number of casts and cells (red cells and white cells along with epithelial cells) in the twelvehour specimen of urine was estimated. The amount of protein in the urine was also measured by a modification of the method of Shevky and Stafford (1923) and the result given in milligrammes. The limits of normality in adults found by Addis are given in table 1.

Several articles have been published about the value of the Addis count in nephritis. Most of them confirm Addis' original findings (Van Slyke, 1930; Lyttle, 1933; Snoke, 1937; Cass, 1939; Murphy and Rastetter, 1938; Gachet, 1941; and Murphy and Peters, 1942). On the other hand Boyle and his co-workers (1937) stated that acute nephritis did not progress to a chronic stage. Only one Addis count, however, was done in each case and repeated counts might have been of more value. In 1942, Rubin and his co-workers, following forty patients with acute haemorrhagic nephritis during the acute stage, found that 120 days (seventeen weeks) were taken for the Addis red cell count to fall to the level of $1,000,000$. This latter figure is taken by Soto (1942), as the upper normal limit. In view of the favourable comments on the value of the Addis count, it was decided to study the method in a series of cases at the Royal Hospital for Sick Children, Glasgow.

The Range of Addis Counts in Normal Children

In the first place, counts were made on the urine of a number of healthy children to establish normal values. The urines of twenty children who did not give a history of previous nephritis, rheumatism, or recent acute infection were examined and counts made. As already stated, the collecting of specimens of urine in children is often difficult and it was decided not to restrict the intake of fluid so rigidly as in adults. On the day of collecting the specimen of urine five ounces of fluid were given at 4 p.m. Thereafter fluids were withheld. The urine was then collected from 7 p.m. to 7 a.m. The count was made as described by Addis (1925). In any 
TABLE 1

THE RANGE (R) AND THE AVERAGE (A) COUNTS OF CASTS, CELLS AND PROTEN IN THE URINARY SEDIMENT OF NORMAL ADULTS AND CHILDREN AND THE PROPOSED UPPER NORMAL LIMITS IN CHILDREN

\begin{tabular}{|c|c|c|c|c|c|}
\hline \multicolumn{2}{|l|}{ Series } & Casts & Red cells & $\begin{array}{l}\text { White and } \\
\text { epithelial cells }\end{array}$ & Protein $\mathrm{mg}$ \\
\hline $\begin{array}{l}\text { Addis } \\
\text { (adults) }\end{array}$ & $\begin{array}{l}\text { R- } \\
\text { A- }\end{array}$ & $\begin{array}{r}0-4,270 \\
1,040\end{array}$ & $\begin{array}{r}0-425,000 \\
65,750\end{array}$ & $\begin{array}{c}32,000-1,835,000 \\
322,000\end{array}$ & $\overline{30}$ \\
\hline $\begin{array}{l}\text { Lyttle } \\
\text { (children) }\end{array}$ & $\begin{array}{l}\text { R- } \\
\text { A- }\end{array}$ & $\begin{array}{r}0-12,916 \\
1,085\end{array}$ & $\begin{array}{r}0-129,000 \\
15,181\end{array}$ & $\begin{array}{c}9,000-2,822,000 \\
322,484\end{array}$ & $\begin{array}{l}3-47 \\
18 \cdot 5\end{array}$ \\
\hline$\underset{\text { (children) }}{\text { Snoke }}$ & $\begin{array}{l}\text { R- } \\
\text { A- }\end{array}$ & $\begin{array}{r}0-29,000 \\
1,230\end{array}$ & $\begin{array}{r}0-800,000 \\
81,000\end{array}$ & - & $\begin{array}{l}5-90 \\
28 \cdot 5\end{array}$ \\
\hline $\begin{array}{l}\text { Author } \\
\text { (children) }\end{array}$ & $\begin{array}{l}\text { R- } \\
\text { A- }\end{array}$ & $\begin{array}{r}0-6,350 \\
1,175\end{array}$ & $\begin{array}{r}0-438,000 \\
61,325\end{array}$ & $\begin{array}{c}9,000-714,000 \\
329,500\end{array}$ & $\begin{array}{l}3-45 \\
22 \cdot 5\end{array}$ \\
\hline \multicolumn{2}{|c|}{$\begin{array}{l}\text { Proposed upper } \\
\text { limits } \quad .\end{array}$} & 10,000 & 600,000 & $2,000,000$ & 55 \\
\hline
\end{tabular}

case where bedwetting was suspected, the urine was discarded. The results are given in table 1 along with those of Addis, Lyttle, and Snoke.

It will be seen that, although the ranges of results varied, the average counts in the present series are similar to those found in normal children and adults by other workers. It was noted that in many urines from these cases the cast count was zero and that the white cell count was often unduly high in female children who were not catheterized. Because of these facts, and from impressions gained during the investigation, it - seemed that almost as much information was to be obtained from the red cell count alone as from all three counts. If this is so, it is of importance as it lessens the time necessary to carry out the count and thus increases its value as a clinical test. From the figures in table 1 , it was accepted that a red cell count of over 600,000 in the twelve-hour specimen of urine was abnormal and should be regarded as an indication of renal impairment.

During the years 1938 to 1944,236 cases of acute nephritis were admitted to the Royal Hospital for Sick Children, Glasgow. Of these children, 218 were examined and their renal function investigated. The whole course of the attack was followed throughout in forty-four of these; on re-examination of the other 174, the urine was tested for albumin and blood and the Addis counts were done on at least two occasions. In each of the latter cases more than one year elapsed between dismissal and re-examination. Indeed, twenty-nine were reexamined after one and a half to two years; thirtysix after two to three years; twenty-three after three to four years; twenty-three after four to five years; twenty-eight after five to six years; sixteen after six to seven years, and five at the end of seven years from dismissal. In addition, the blood pressure and the non-protein nitrogen (Folin and Svedberg, 1930) were estimated. If any of these tests were unsatisfactory, the serum proteins were estimated by the micro-Kjeldhal method, and the urea concentration test of MacLean together with the urea clearance test of Van Slyke was done.

On the findings of the Addis counts, the cases were classified as shown in table 2 , and it was possible to compare the value of the Addis count with that of the other tests of renal function. It

TABLE 2

STAGE OF NEPHRITIS AT THE FINAL EXAMINATION (218 CASES)

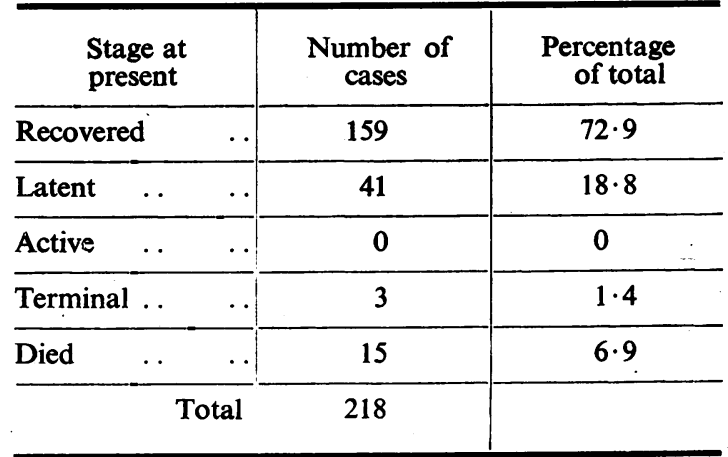

was found that 159 (72.9 per cent.) of the 218 cases had recovered, that is, all the tests including the Addis counts were normal. Forty-one cases (18.8 per cent.) were regarded as being in a latent stage. In sixteen of these there was mild albuminuria, and in all but one, in which the urine contained a trace of albumin, the Addis count (red cell) was raised. The other excretion tests were satisfactory in every instance. It will therefore be seen that in 
twenty-five $(41-16)$ cases the raised red-cell Addis count was the only indication that the renal function might still be active. This test, therefore, detects the presence of renal damage even when the blood pressure and the non-protein nitrogen are normal and the renal function found to be unimpaired by the urea clearance and concentration tests. When the latent stage is persistent, it is considered improbable that the renal lesion will heal. Snoke (1937) believes that if the Addis count does not return to normal within two years recovery is unlikely. The findings in the present series, where thirty-five of the forty-one cases have been in the latent stage for more than two years, would seem to confirm this belief.

In three cases (1.4 per cent.), all the tests were unsatisfactory and the Addis counts raised. As these children had had nephritis for over three years it may be assumed that the lesion was progressive and recovery unlikely. It was found, therefore, that the Addis count, although raised in the terminal stage of nephritis, was not more helpful than the more commonly employed tests. The appearance of the patient, the albuminuria, nitrogen retention, and poor urea concentration and clearance tests showed only too well the presence of marked and progressive renal impairment.

Of the fifteen patients $(6.9$ per cent.) who died, the cause of death was acute infection (nine cases), acute hypertensive encephalopathy (two cases), and uraemia (four cases). Two of the latter four cases died within twelve weeks of the onset of the initial attack. The other two progressed slowly over a period of years to a chronic stage with hypertension and nitrogen retention before dying in uraemia. The range and average Addis counts in each stage are given in table 3.

Of the 218 cases, forty-four, admitted between May, 1943, and December, 1944, were under observation from the onset of the disease. Addis counts were done at regular intervals. On dismissal, tests of the urine were normal in thirty-eight cases; in the other six there was a trace of albumin and an occasional red cell in the urine on microscopic examination. The Addis red cell count, however, in every instance was over $1,000,000$ and in one instance as high as $20,000,000$. The blood pressure, non-protein nitrogen, serum proteins, and urea concentration and clearance tests were satisfactory. It is, therefore, evident that on dismissal the Addis count in thirty-eight of these patients revealed evidence of renal mischief undetected by other tests.

The Addis counts were repeated at regular intervals after dismissal; in thirty-nine cases they returned to normal, but in five cases the red cell count has remained raised, indicating that the renal lesion is still present although possibly latent. It was found that in the thirty-nine cases the shortest time taken for the Addis count to fall below the upper limit of 600,000 was twelve weeks, the longest time fifty-two weeks, and the average time sixteen weeks. This average time is rather less than that given by Rubin and his co-workers (1942) who, taking an upper normal limit of 1,000,000 (Soto, 1942), found that this level was reached after seventeen weeks.

It was seen that thirty-six of the forty-four patients were dismissed from hospital within eleven weeks of the onset of the disease. As the red cell Addis count takes, on the average, sixteen weeks to return to normal, most of these patients were dismissed while the Addis counts were raised. The cases were regarded as recovered, at least temporarily, only when the Addis count and all the other tests were normal. Prolonged hospitalization may have a beneficial effect on the prognosis of the disease.

\section{Illustrative Cases}

The counts in two representative cases, one healed and one in the latent stage, are given.

E. T. (male), aged seven years, was dismissed on Feb. 11, 1944, four weeks after the onset of the initial attack of acute nephritis. On dismissal, the urine was clear to routine tests (see table 4).

H. W. (male), aged ten years, was dismissed on Aug. 30, 1943, seven weeks after the onset of a second attack of acute nephritis. (The first attack had been in October, 1938, and had lasted nineteen weeks.) The urine contained a trace of albumin on dismissal, but there was no nitrogen retention nor hypertension and the renal excretion tests were good.

TABLE 3

ADDIS COUNTS: THE RANGE (R) AND AVERAGE (A) ADDIS COUNTS IN EACH STAGE

\begin{tabular}{|c|c|c|c|c|c|}
\hline Stage & No. & Casts & Red cells & $\begin{array}{l}\text { White and } \\
\text { epithelial cells }\end{array}$ & Protein $\mathrm{mg}$. \\
\hline Recovered & 159 & $\begin{array}{lr}\text { R. } & 0-8,650 \\
\text { A. } & 842\end{array}$ & $\begin{array}{r}0-552,000 \\
75,445\end{array}$ & $\begin{array}{r}0-7,695,000 \\
486,325\end{array}$ & $\begin{array}{r}3-36 \\
19 \cdot 79\end{array}$ \\
\hline Latent & 41 & $\begin{array}{l}0-22,600 \\
6,725\end{array}$ & $\begin{array}{c}517,000-6,324,000 \\
1,386,000\end{array}$ & $\begin{array}{r}0-2,360,000 \\
654,510\end{array}$ & $\begin{array}{c}36-90 \\
72\end{array}$ \\
\hline Terminal & 3 & $\begin{array}{l}\text { R. } 0-58,000 \\
\text { A. } \quad 16,840\end{array}$ & $\begin{array}{c}960,000-3,670,000 \\
2,071,330\end{array}$ & $\begin{array}{r}45,000-4,860,000 \\
1,635,000\end{array}$ & $\begin{array}{c}320-1,230 \\
735\end{array}$ \\
\hline
\end{tabular}


TABLe 4

SUMMARY OF TESTS IN CASE E. T.

\begin{tabular}{c|r|r|r}
\hline Date & Casts & Red cells & $\begin{array}{c}\text { White and } \\
\text { epithelial cells }\end{array}$ \\
\hline 1944 & & & \\
Feb. 11 & 35,000 & $3,075,000$ & $4,640,000$ \\
Mar. 9 & 11,200 & $1,481,500$ & $1,865,000$ \\
Apr. 8 & 4,200 & 925,000 & 768,000 \\
May 6 & 0 & 498,000 & 326,000 \\
Aug. 18 & 0 & 322,000 & 196,000 \\
Dec. 27 & 0 & 48,600 & 126,000 \\
1945 & 1,200 & 54,300 & 286,000 \\
Apr. 19 & 0 & 0 & 48,000 \\
Nov. 14 & 0 & & \\
\hline
\end{tabular}

Since then, except for an occasional haze of albumin, the urine has remained clear. There has been no evidence of renal failure (see table 5).

TABLE 5

SUMMARY OF TESTS IN CASE H. W.

\begin{tabular}{c|r|r|r}
\hline Date & \multicolumn{1}{|c|}{ Casts } & Red cells & White cells \\
\hline $\begin{array}{r}\text { 1943 } \\
\text { Aug. 29 }\end{array}$ & 92,200 & $28,700,000$ & \\
Sept. 30 & 24,500 & $16,710,000$ & $3,280,000$ \\
Oct. 26 & 11,400 & $2,890,000$ & $1,465,000$ \\
1944 & & & \\
Aug. 5 & 0 & 968,000 & 5600 \\
Oct. 10 & 1,240 & $1,031,000$ & 83,000 \\
Nov. 7 & 4,650 & $1,968,000$ & 426,000 \\
Dec. 12 & 11,850 & $7,020,000$ & $5,125,000$ \\
1945 & 0 & $1,369,000$ & 236,000 \\
Mar. 20 & 0 & $1,710,000$ & 526,000 \\
June 27 & 0 & $5,853,000$ \\
Dec. 23 & 16,450 & $6,256,000$ & \\
\hline
\end{tabular}

It was suggested by Snoke (1937) and Gachet (1941) that recovery should not be considered to be complete until the Addis count had been normal on numerous occasions for at least one year. In the present series, 153 of the 218 cases had had normal Addis counts for more than one year and six cases for more than eight months. There had been no evidence of relapse in these cases. It can therefore be said that when the Addis count returns to normal and remains so on several examinations, the renal lesion has healed and that a relapse is unlikely.

\section{Summary and Conclusions}

A description of the Addis count of the urinary sediment is given. The normal limits for casts, red cells, and white cells in the twelve-hour specimen of urine are defined. The red cell Addis count is thought to give as much information as the cast or white cell count in children. In the twelve-hour specimen a total excretion of 600,000 red cells is given as the upper limit of normal.
Using the routine renal function tests as well as the Addis count, 218 cases of acute haemorrhagic nephritis were examined; 174 were investigated after the acute attack had subsided, and forty-four were followed throughout the course of the illness.

Forty-one of the 218 cases were found to be in a latent stage, and in twenty-five of the forty-one the raised Addis count was the only sign of a persisting renal lesion.

In each of the forty-four cases, which were under observation from the onset of illness, the Addis count was raised on dismissal from hospital, and in thirty-eight was the only indication of renal damage at that time. The Addis count (red cell) returned to normal within an average of sixteen weeks in thirty-nine cases, but in five has remained above the 600,000 level.

It is suggested that the Addis red cell count gives a better indication of the prognosis in acute haemorrhagic nephritis than any other test of renal function and that it should be more frequently employed in assessing the prognosis in individual cases.

I wish to thank Dr. Stanley Graham for his help and advice in preparing this paper.

\section{REFERENCES}

Addis, T. (1925). J. Amer. med. Ass., 85, 163.

- (1926). J. clin. Invest., $2,409$.

- (1928). Amer. J. med. Sci., 176, 617

- (1931). Johns Hopk. Hosp. Bull., 49, 203, 271.

Aldrich, C. A. (1930). J. Amer. med. Ass., 94, 1637.

Boyle, H. A., Aldrich, C. A., Frank, A., and Borowsky, S. (1937). J. Amer. med. Ass., 108, 1496.

Cass, J. M. (1939). Arch. Dis. Childh., 14, 137.

Folin, O., and Svedberg, A. (1930). J. biol. Chem., 88, 85.

Gachet, F. S. (1941). Amer. J. Dis. Child., 61, 1175.

Goldring, W. (1931). J. clin. Invest., 10, 355. and Wyckoff, J. (1930). Ibid., 8, 569.

Lyttle, J. D. (1) (1933). Ibid., 12. 87, 95.

MacLean, H., and de Wesselow, O. L. V. (1919). Quart. J. Med., 12, 347.

Moore, N. S., and Van Slyke, D. D. (1930). J. clin. Invest., 8, 337.

Murphy, F. D., and Peters, B. J. (1942). J. Amer. med. Ass., 118, 184.

and Rastetter, J. W. (1938). Ibid., 111, 668.

Nathhorst, H. (1940). Ann. Paediatr., 155, 285.

Rubin, M. I., Rapoport, M., and Waltz., A. D. (1942). J. Pediat., 20, 32.

Shevky, M. C., and Stafford, D. D. (1923). Arch. intern. Med., 32, 222.

Snoke, A. W. (1937). Amer. J. Dis. Child., 53, 673.

(1938). J. Pediat., 12, 473.

Soto, P. E. (1942). Quoted by Rubin et al. (1942). Ibid., 20, 32.

Van Slyke, D. D., Stillman, E., Möller, E., Erlich, W., McIntosh, J. F., Leiter, L., Mackay, E. M., Hannon, R. R., Moore, N. S., and Johnstone, C. (1930). Medicine, 9, 257.

Wallgren, A. (1939). Arch. Dis. Childh., 14, 271. 